DEMOGRAPHIC RESEARCH

VOLUME 41, ARTICLE 27, PAGES 781-814 PUBLISHED 1 OCTOBER 2019

http://www.demographic-research.org/Volumes/Vol41/27/

DOI: $\quad$ 10.4054/DemRes.2019.41.27

Research Article

\title{
Civilian killings and disappearances during civil war in El Salvador (1980-1992)
}

\section{Amelia Hoover Green}

\section{Patrick Ball}

(C) 2019 Amelia Hoover Green \& Patrick Ball.

This open-access work is published under the terms of the Creative Commons Attribution 3.0 Germany (CC BY 3.0 DE), which permits use, reproduction, and distribution in any medium, provided the original author(s) and source are given credit.

See https://creativecommons.org/licenses/by/3.0/de/legalcode 


\section{Contents}

$\begin{array}{lll}1 & \text { Introduction } & 782\end{array}$

$\begin{array}{lll}2 & \text { Background } & 783\end{array}$

$3 \quad$ Methods $\quad 785$

$3.1 \quad$ Methodological overview $\quad 785$

3.2 Assumptions of the model 786

$\begin{array}{lll}3.3 & \text { Data sources } & 787\end{array}$

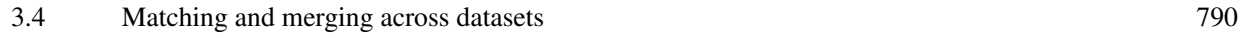

$\begin{array}{lll}3.5 & \text { Stratification } & 792\end{array}$

$\begin{array}{lll}3.6 & \text { Estimation procedure } & 795\end{array}$

$4 \quad$ Results $\quad 799$

$\begin{array}{lll}4.1 & \text { Spatial variation } & 799\end{array}$

$\begin{array}{lll}4.2 & \text { Temporal variation } & 802\end{array}$

$\begin{array}{lll}4.3 & \text { Global estimates } & 803\end{array}$

$\begin{array}{lll}\text { 4.3.1 } & \text { Sums over strata } & 805\end{array}$

$\begin{array}{lll}5 & \text { Discussion } & 807\end{array}$

$\begin{array}{llr}6 & \text { Conclusions } & 808\end{array}$

$\begin{array}{lr}\text { References } & 810\end{array}$ 


\title{
Civilian killings and disappearances during civil war in El Salvador (1980-1992)
}

\author{
Amelia Hoover Green ${ }^{1}$ \\ Patrick Ball ${ }^{2}$
}

\begin{abstract}
BACKGROUND

Debate over the civilian toll of El Salvador's civil war (1980-1992) raged throughout the conflict and its aftermath. Apologists for the Salvadoran regime claimed no more than 20,000 had died, while some activists placed the toll at 100,000 or more. But no rigorous estimate was available to settle the question, which has returned to prominence because of newly opened war-crimes trials.
\end{abstract}

\section{OBJECTIVE}

Estimate the total number of civilian killings and disappearances in El Salvador during 1980-1992.

\section{METHODS}

We match and merge four lists of reported civilian killings and disappearances, gathered by multiple organizations - approximately 20,000 unique episodes in all. We use loglinear modeling to estimate the number of uncounted cases from patterns of list overlap. To account for uncertainty in model selection, we use Bayesian model averaging over the set of decomposable graphical models.

\section{RESULTS}

We estimate that there were about $71,629(60,326,83,775)$ civilian killings and disappearances during the conflict, or about 1-2\% of El Salvador's prewar population. Correlations between recorded deaths and estimated deaths are imperfect over both time and space.

\section{CONCLUSIONS}

Unusually, our conservative global estimate is similar to nonstatistical 'expert guesses.' However, the estimated distribution of civilian killings and disappearances does not closely track the reported distribution over time or space. Our approach achieves high quality estimates, even in the presence of relatively sparse data.

\footnotetext{
${ }^{1}$ Drexel University, Philadelphia, USA. Email: aah92@drexel.edu.

${ }^{2}$ Human Rights Data Analysis Group, San Francisco, USA. Email: pball@hrdag.org.
} 


\section{CONTRIBUTION}

This is the first rigorous estimate of civilian killings and disappearances in the Salvadoran civil war. Both the global estimates and estimates for specific spatiotemporal strata will inform ongoing accountability processes.

\section{Introduction}

The civil war in El Salvador ended over a quarter century ago, but the total mortality due to violence is still unknown. Reasonable educated guesses about the total magnitude of violent death hover around 75,000 (see, e.g., Betancur, Figueredo Planchart, and Buergenthal 1993; Stanley 1996; Wood 2003; Viterna 2013). These guesses far exceed both total observed, enumerated deaths and the guesses offered by apologists for the Salvadoran regime of the 1980s. This article employs multiple systems estimation to estimate violent mortality, a category that includes both direct killings and forced disappearances, among Salvadorans from 1980 to 1992. By integrating four data sources, we identify 20,048 unique killings and disappearances. Analyzing the patterns in which killings are documented among the four data sources (the inclusion patterns), we estimate a total death toll of approximately $71,629(60,326,83,775)$ during $1980-1992$, or approximately $1-2 \%$ of the total prewar population of El Salvador. ${ }^{3}$ In addition, we examine variation in violent deaths across time and space.

Accurate inferences about patterns of violent mortality provide an important foundation for historical memory and transitional justice processes (Popkin and Roht-Arriaza 1995; Bakiner 2013). Estimating patterns of violent mortality is also a prerequisite for understanding the causes of wartime violence against civilians. Unfortunately, variation in levels of violence for different periods, or for different regions, can seldom be established with accuracy. Thus, in addition to providing the first model-based estimates of violent mortality in El Salvador, this project opens the door for more reliable quantitative theory-testing about its causes.

Our findings are directly relevant in contemporary El Salvador. In July 2016, the country's high court struck down the blanket amnesty provision of the 1992 peace accords. Thus, more than four decades since the beginning of the war, and 25 years after its end, prosecutions of accused war criminals have begun anew. While there exist extensive forensic investigations of a few massacres, most civilian killings remain not only underinvestigated but - as this study shows - undocumented. A few prosecutions took place prior to the amnesty; nearly all of these involved low-level perpetrators rather than the commanders who ordered or allowed the broader pattern of violence. Holding comman-

\footnotetext{
${ }^{3}$ Note that we also derive other, similar high-quality global estimates; see Table 7.
} 
ders legally accountable demands a more accurate accounting for patterns of violence. The demography of conflict and violence can be a significant contributor to transitional justice processes. To take but one example, the International Criminal Tribunal for the Former Yugoslavia made extensive use of demographic evidence across a number of prosecutions (Tabeau 2009).

\section{Background}

El Salvador is a small country on the Pacific coast of Central America. Its contemporary population is approximately 6.4 million, having risen from approximately 5.4 million at the close of its civil war in 1992 and 4.5 million at the war's outset in 1980 (United Nations 2017). In both size (about 8,000 square miles) and population density (about 800 people per square mile today), it is similar to the US state of Massachusetts. This makes El Salvador the most densely populated country in the mainland Americas, although population density varies significantly across the country's 14 departments. Unlike many countries in Latin America, including its neighbor Guatemala, today El Salvador has little ethnic diversity. Following a failed uprising in 1932, indigenous people were targeted for massacre by the country's military rulers. Thousands or tens of thousands of indigenous (and indigenous-appearing) Salvadorans, particularly in the western region of the country, were killed outright in this bloodshed, known as la matanza (the massacre) (Gould and Lauria-Santiago 2009).

La matanza prefigures the Salvadoran civil war of 1980-1992 in several ways, particularly the military government's use of massive, disproportionate repression against perceived threats to the country's political and economic regime. Examining the roots of the civil war, Stanley (1996) describes a 'protection racket state': a small agrarian elite granted formal control of government to El Salvador's military in exchange for labor coercion on the country's coffee, cotton, and sugar plantations. A succession of military governments ruled the country, with infrequent interruptions, beginning at independence. Cabarrús (1983) estimates that approximately $40 \%$ of El Salvador's rural families owned no land at all in 1975, five years prior to the onset of the war. At the same time, 463 properties accounted for nearly $30 \%$ of all arable land (Byrne 1996). Wood (2003) refers to this situation as a 'classic oligarchy.'

From the mid-1960s until 1972, Salvadoran society experienced a period of decreased repression and increased political activity, including unionization efforts and peasant organizing. However, this brief political opening snapped shut once again in 1972, when military leaders overturned the election of Jose Napoleon Duarte, a civilian member of the Christian Democratic party, and a champion of moderate reform, to the Presidency. The 1960s and 1970s also brought significant changes to the Roman Catholic church in El Salvador, primarily via Liberation Theology. The public face of Liberation 
Theology in El Salvador was Oscar Arnulfo Romero, Archbishop of the Diocese of San Salvador from 1977 until his death, by assassination, in May 1980. Romero, initially seen as a conservative choice, spoke boldly about conditions in the country via weekly radio sermons, which galvanized leftist organizing in many areas of the country.

Civil war was not a foregone conclusion, however. As late as the mid-1970's, significant tensions existed within El Salvador's various reform movements regarding the possibility of peaceful reforms and the relative importance of political, versus military, organizing. Scholars of the conflict agree that the path to war was solidified by a wave of violent repression that effectively annihilated the moderate, reformist left in El Salvador by the late 1970's. El Salvador's rebel organization, the Farabundo Martí National Liberation Front (Frente Farabundo Martí para la Liberación Nacional, FMLN), took shape in $1980 .^{4}$

On January 10, 1981, the FMLN launched what it termed its 'final offensive.' FMLN leadership had calculated, incorrectly, that a sudden show of force would foment a popular uprising, similar to the revolution that had overthrown Nicaragua's dictatorship in 1979. Instead, the 'final' offensive became the first nationally coordinated battle of a twelveyear civil war. And, while the initial offensive failed to produce mass uprising, it signaled FMLN ascendancy. The Salvadoran state, including regular and special forces within the Salvadoran army, paramilitary security forces, and allied death squads, wielded devastating violence against ordinary citizens but nearly lost their conflict with the well-trained and highly disciplined FMLN at a number of junctures. Both conventional wisdom and scholarly accounts suggest that, particularly early in the conflict, state forces and their informal allies committed the vast majority of violence against civilians, turning many erstwhile civilian allies into FMLN supporters.

Yet the Salvadoran military had powerful allies elsewhere: The American administration of Ronald Reagan viewed El Salvador as a key Cold War battleground, eventually spending billions of dollars on military training, funding, and materiel (see, e.g., Bacevich et al. 1988; Schwarz 1991). The FMLN controlled over a third of the country's territory by 1982-1983, when aerial bombardments from American-supplied attack helicopters forced it to cease conventional tactics and revert to small-unit guerrilla warfare. During approximately 1984-1988, stalemate reigned, while the FMLN regrouped in its areas of control. A second 'final' offensive, on the capital city of San Salvador in November 1989, showed the FMLN's continued power. With no decisive end in sight and the Cold War waning, both sides agreed to begin peace talks, which were concluded at Cha-

\footnotetext{
${ }^{4}$ The FMLN united four Communist groups: the Popular Forces of Liberation (Fuerzas Populares de Liberación, FPL), the Revolutionary Army of the People (Ejército Revolucionario del Pueblo, ERP), the National Resistance (Resistencia Nacional, RN), and the Armed Forces of Liberation (Fuerzas Armadas de Liberación, FAL, the armed wing of the Salvadoran Communist Party). A fifth organization, the Revolutionary Party of Central American Workers (Partido Revolucionario de Trabajadores Centroamericanos, PRTC), grew from a rather different strand of Central American organizing, namely the movement for pan-Central American selfdetermination. See Montgomery (2018) for further details of the alliance.
} 
pultepec, Mexico, in December 1991. The eventual peace agreement, which included plans for military reforms, a truth commission, and a general amnesty, entered into force in February 1992.

\section{Methods}

The goal of this project is to produce rigorously defensible statistical estimates of violent mortality in the Salvadoran civil war (defined for our purposes as 1980-1992), including global death tolls and insight on variation over space and time. Retrospective mortality surveys are now a common tool for estimating conflict tolls, particularly in the immediate post-conflict period, but these tools were in their infancy and not used in 1992. ${ }^{5}$ While several organizations collected data on killings during and immediately after the conflict, these data were created with legal action or historical memory - not vital statistics - in mind. Furthermore, the massive displacement and depopulation of the Salvadoran population during the conflict would have made probability sampling challenging or impossible. In this section, we describe how our research team employed multiple systems estimation (MSE) to create population inferences from nonrepresentative sources.

\subsection{Methodological overview}

Multiple systems estimation (MSE), also known as capture-recapture or multiple-recapture analysis, is a long-standing technique for evaluating the size of populations that cannot be adequately sampled (because no sample frame exists, because of social stigma, or for other reasons). It has been widely applied in the epidemiology of infectious diseases (Jansson, Arneborn, and Ekdal 2005), including measles (Davis et al. 1993), HIV disease (e.g., Mastro et al. 1994; Lewden et al. 2006), tuberculosis (Van Hest et al. 2008), and Ebola virus (Gignoux et al. 2015). Researchers also frequently use MSE to estimate the size of under-registered, stigmatized populations, such as users of illegal drugs (e.g., Mastro et al. 1994), unhoused people (e.g., Berry 2007), and sex workers (e.g., Geibel et al. 2007). MSE has been applied to conflict mortality in several cases (for an overview, see Brunborg, Tabeau, and Urdal 2006; Ball and Price 2019), including Guatemala (Ball et al. 1996), Kosovo (Ball et al. 2002), Peru (Ball et al. 2003), Bosnia (Tabeau 2009), and Colombia (Lum et al. 2010). More recently, MSE has been used to estimate the number

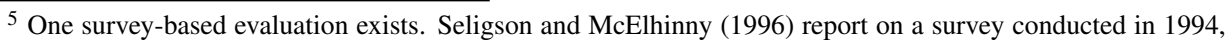
"primarily[...] to measure the political attitudes and behaviors of the population[...]," which included a question about violence. While Seligson and McIlhenny's data cannot estimate mortality directly, $34 \%$ of respondents (no confidence interval is given) reported having at least one family member killed in the conflict.
} 
of people held in slavery (e.g., Bales, Hesketh, and Silverman 2015, and a November 2017 special issue of Chance magazine).

As a method for estimating populations, MSE has been validated in a few cases (see Bird and King 2017 for a review). While airtight validation is impossible in the context of wartime violence, there are useful comparisons with other methods. For example, after mass killings in Kosovo during March-June, 1999, Ball et al. (2002) estimated, on the basis of approximately 4,400 cases documented by 2000, that approximately 10,000 $(9,002,12,022)$ persons had been killed. These estimates overlapped those of a retrospective population-based survey conducted in the aftermath of the conflict, which suggested that during a slightly longer period, approximately $12,000(5,500-18,300)$ persons died (Spiegel and Salama 2000). Ultimately, using information gleaned over the following dozen years, the Kosovo Memory Book project directly documented approximately 14,000 deaths related to the conflict (Krüger and Ball 2014), including 10,500 during the period estimated by Ball et al. (2002).

MSE is best thought of as a collection of specific techniques to estimate list incompleteness by examining list overlaps. By 'list incompleteness' (or 'under-reporting'), we mean the proportion of the true total population that is not captured by any list. By 'list overlaps,' we mean the subset of known population members (e.g., civilians listed as killed in a conflict) that appear in more than one list. In this article, we refer to 'lists,' 'systems,' and 'datasets' interchangeably to mean any collection of casualty data. Our approach places log-linear models for population estimation (Bishop, Fienberg, and Holland 1975) in a Bayesian framework, which calculates a weighted average over all possible log-linear models (Madigan and York 1997). The Bayesian framework allows us to incorporate uncertainty about model selection over the thousands of possible log-linear models into the estimates and variances reported below.

\subsection{Assumptions of the model}

The simplest implementation of MSE, employing only two systems, relies on four key assumptions. Two-system models must assume (1) that the population of interest is 'closed,' i.e., that no members of the population are created or removed during the observation period; (2) that matching across lists is accurate; (3) that the probability of being listed on a given list is equal for all population members ('homogeneous capture probability'); and (4) that selection into one list does not affect the probability of selection into the other ('independence of systems') (Lum, Price, and Banks 2013).

Assumption (1) is met: Except in marginal cases in which persons thought to be dead are found alive, the population of people killed violently in El Salvador does not change 
retroactively. ${ }^{6}$ We believe assumption (2) is met but discuss the potential for matching errors below under 'Matching and merging across datasets.' There is no way to fully meet assumption (3), but we can significantly decrease heterogeneity in capture probabilities via stratification. Because we employ four systems, we can explicitly model violations of assumption (4) and therefore need only assume that there is no four-way interaction among lists. We are confident that this assumption is met.

\subsection{Data sources}

We integrate four data sources in the analysis: a dataset created by researchers at the non-governmental Commission for Human Rights in El Salvador (Comisión de Derechos Humanos de El Salvador, CDHES); a dataset coded from the files of the legal aid office of the Archbishopric of San Salvador (identified here as El Rescate, after the organization that completed the coding); a dataset of acts of violence reported directly to the United Nations-sponsored Truth Commission for El Salvador (UNTC); and a dataset of acts of violence reported to the UNTC by other organizations (UNTC-2).

CDHES began operations in 1978, as government repression increased in the run-up to war. It maintained offices in San Salvador and routinely sent investigators to other locations. CDHES staff, operating under constant threat, collected detailed victim and witness testimonies throughout the conflict. Immediately following the close of the conflict, these files were coded for analysis and, in many cases, presented to the UNTC. Ball (2000: 15) discusses the procedure: "Between 1979 and 1991, the CDHES took more than 9,000 interviews that were recorded in written form as [legally sworn] testimonies[...]. The goal of [the database] project was to target individual perpetrator [legal] responsibility," primarily via connecting specific allegations of violence to specific military officers. Ball used a FoxPro database with a relatively complex relational structure to encode complex victim and witness testimonies: Every testimony could refer to one or more incidents, in which one or more types of violence might have occurred to one or more victims; the testimony might associate each violation with one or more perpetrators (Ball 1996). Individual victims and the locations at which violations occurred were also described and encoded. Ultimately, CDHES testimonies yielded evidence of over 29,000 total violations; however, just 4,858 of these were killings or disappearances, and only 3,668 of these included name, department, and year data.

The second data source employed in this project, El Rescate, is the result of a partnership between the Roman Catholic diocese of San Salvador and the American NGO El Rescate, based in Los Angeles (Howland 2008). In an attempt to combat impunity, El Rescate coded and analyzed both violence reported to Tutela Legal (the legal aid of-

\footnotetext{
${ }^{6}$ Moreover, to the extent that people listed as dead are later shown to be alive, this does not lead to biased MSE estimates unless these cases are both quite numerous and non-random (Kendall 1999).
} 
fice of the diocese) and hundreds of officer biographies. Notably, El Rescate researchers coded only information published by Tutela Legal, and cases that could not be directly investigated by Tutela Legal staffers could not be published. This fact, combined with the inaccessibility of many parts of the country during the conflict, means that El Rescate data focus on 'investigatable' acts of violence, particularly those that occurred in areas of the country accessible to staffers.

The diocesan legal aid office changed institutional forms during the conflict. From its founding in 1975, the legal aid office was known as Socorro Jurídico. In 1982, the office was reorganized under the name Tutela Legal (the source of the data used here), while Socorro Jurídico became a separate organization. This may have caused loss of data. The data coded by El Rescate, unlike data from other organizations, show lower levels of violence in 1980 and 1981, followed by a spike in 1982 . We speculate that the reorganization of the diocesan legal aid apparatus caused some data loss for 19801981, as well as a changing level of available resources for documentation. This may have resulted in variation in the probability of documenting deaths over different periods. From Tutela's reports, El Rescate coded more than 22,000 separate acts of violence against civilians, including 8,137 lethal violations, of which 6,442 included name, department, and year information. Howland (2008) describes El Rescate's process.

The final two data sources were the products of the United Nations-sponsored Truth Commission for El Salvador (Betancur, Figueredo Planchart, and Buergenthal 1993). These datasets, which we refer to as UNTC and UNTC-2, were collected and tabulated separately and rely on different (though overlapping) sources of information. Broadly, the peace agreement that formed the UNTC stated, "The Commission shall have the task of investigating serious acts of violence that have occurred since 1980 and whose impact on society urgently demands that the public should know the truth" (Betancur, Figueredo Planchart, and Buergenthal 1993, part I, section C). The Truth Commission's work was due to be completed in six months, meaning that the time for gathering testimonies was short. The Commission maintained an open-door policy (Betancur, Figueredo Planchart, and Buergenthal 1993, part I, section D) at offices in San Salvador, Chalatenango, Santa Ana, and San Miguel. According to the Commission, "The whole of Salvadoran society, institutions and individuals familiar with acts of violence were invited to make them known to the Commission, under the guarantee of confidentiality and discretion" (I, D). Individual testimonies are collected in the UNTC data, while testimonies from organizations - including CDHES and El Rescate - are collected in UNTC-2. Were the overlap between CDHES and UNTC-2 or El Rescate and UNTC-2 complete, we would discard UNTC-2 for lack of new information. Somewhat mysteriously, though, this is not the case. UNTC data yield 6,474 reported lethal violations (including 6,195 with name, department, and year information), and UNTC-2 (indirect) data yield 10,420 (including 9,800 with name, department and year information).

In all, before canonicalization or deduplication, the data on lethal violence across 
these four organizations yields 29,889 records, each of which represents one report of one killing or disappearance perpetrated against one civilian victim. Given the widely varying locations, capabilities, and sociopolitical associations of the data collection organizations, it is unsurprising that each source yields a different narrative about the burden of lethal violence over time, space, and reported perpetrator. Figures 1 and 2 show the datasets' differing narratives about the burden of violence by department (Figure 1) and by year (Figure 2).

\section{Figure 1: $\quad$ Log per-capita lethal violence, four datasets}
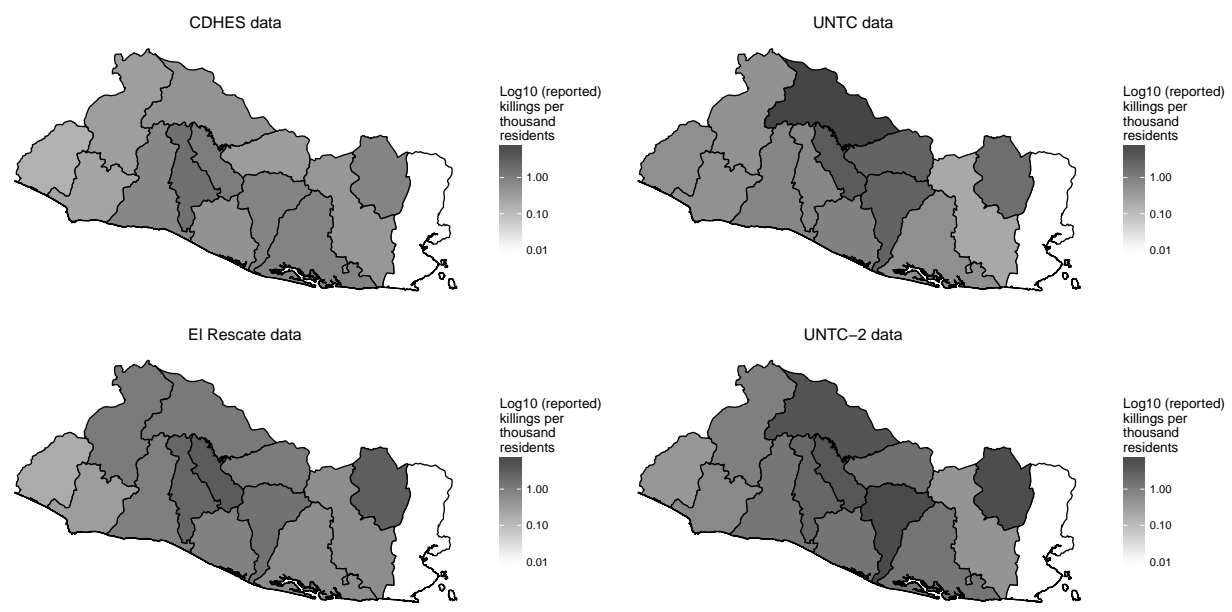
Figure 2: $\quad$ Lethal violence by year, four datasets

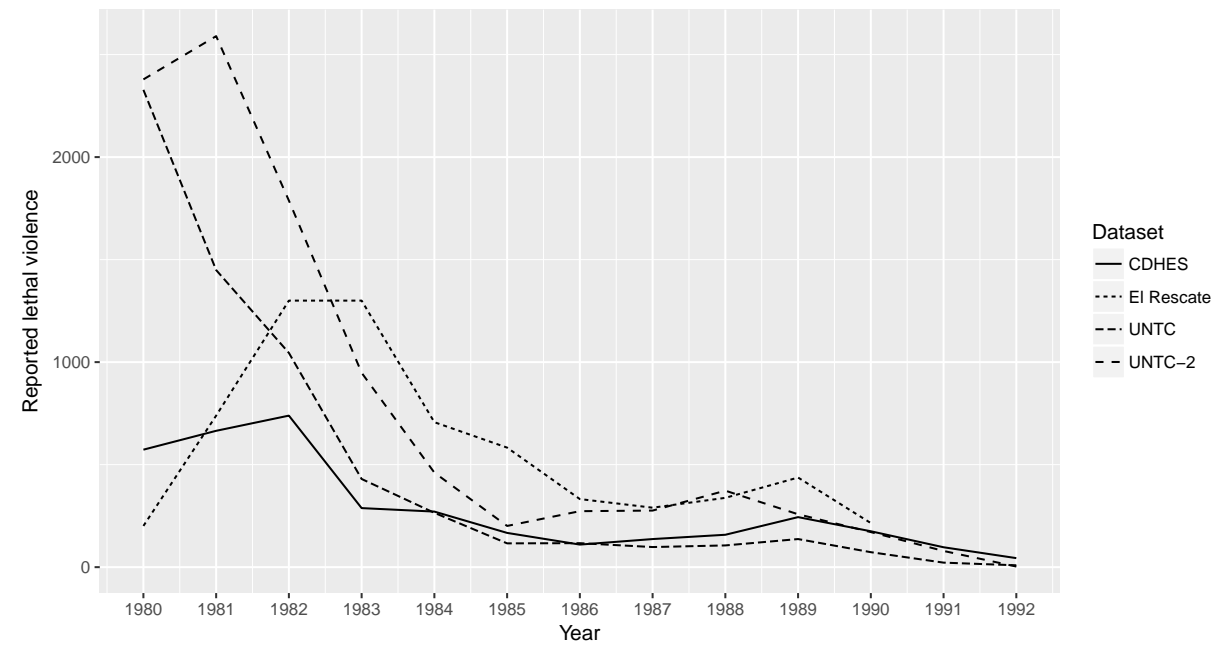

These differences are consequential, both for purposes of historical memory and for purposes of legal accountability. Moreover, in other investigations of civilian death tolls from armed conflict, researchers have estimated that reported episodes of violence often represent one third to one half the total burden of violent death (e.g., Ball 1996; Ball et al. 2002 [and see Spiegel and Salama 2000], Ball et al. 2003). In El Salvador, experts have long guessed that the total civilian death toll exceeds the recorded civilian death toll by at least a factor of three (Stanley 1996; Wood 2003; Viterna 2013). If these guesses are correct, the next question is: how representative are the existing data? Do unreported deaths follow patterns similar to those of reported deaths, or do existing data imply a biased narrative? Which source is closest to the truth, and how should that affect our assessments of Salvadoran mortality data?

\subsection{Matching and merging across datasets}

We prepared the data for estimation in two key ways: canonicalization and matching. First, all data were canonicalized to draw from the same controlled vocabulary of violence types, perpetrator types, geographies, and so on. For example, locations, accused perpetrators, or violence types may have been misspelled, or definite articles ('el,' 'la') omitted. After canonicalization, all names that refer to the same entities are the same, so that these four previously unstandarized datasets can be compared. We also eliminated from consideration cases that included no victim name, those for which the department 
where the violence occurred was unknown, and those for which the year of the violence was unknown. Removing cases with insufficient information for matching left 26,105 total 'matchable' killings and disappearances. Notably, the level of information recorded varied considerably by dataset. CDHES data, for example, are less likely than other sources to include name, department, and year information, and therefore less likely to contribute to our estimates.

Second, for each of these episodes of violence, we detected and merged duplicates. A human reader reviewed records that shared one or more common field values (first name, last name, department, month or year, or other values). They determined which records refer to the same victims, and labeled these as co-referent by assigning them a common key. ${ }^{7}$ To take a hypothetical example, if CDHES data list a person named 'Rogelio Sanabria Caras' murdered by 'state forces' in the department of Sonsonate in 1980, we need to determine whether that record represents the same act of violence recorded by El Rescate data - which might show a record for 'Rogelio Sanabria,' killed by the National Guard in Sonsonate in 1981 - and/or UNTC data - which might show 'Roger Sanabria Caras,' Sonsonate, 1980, no perpetrator listed.

After matching, we merged records that (in our readers' judgment) were represented more than once, including records represented more than once in the same dataset and those represented in multiple datasets. The merge process created a single record for each unique reported killing that included our judgment about the most accurate and complete information for each field. In most cases, where matching records differed on specifics, we chose the majority opinion. However, if one dataset included more specific information that still accorded with general information from (an)other dataset(s), we included the more specific information in the representative record. Thus, in the hypothetical case above, the representative record lists the victim's name as 'Rogelio Sanabria Caras,' the date of death as 1980, and the El perpetrator as the National Guard. This case was reported by CDHES, El Rescate, and UNTC, but not by UNTC-2. This victim is denoted in the dataset as having an inclusion pattern of 1110, where 1 and 0 represent the victim being included or not in each of the four datasets (in the order given here). The inclusion pattern denotes a 'cell,' that is, an element in the table of counts, such as that shown in the rows of Table 1 . Table 1 shows the counts of records by the inclusion pattern in these

\footnotetext{
${ }^{7}$ Perfect matching across datasets is, as noted above, an assumption of all MSE models. Overmatching can lead to downward bias in MSE estimates, while undermatching can lead to upward bias. Author 1 extensively reviewed the reader's match decisions and found no clear errors, but it is important to acknowledge the possibility of undetected errors in matching. For example, in the Salvadoran case, whole families were sometimes killed in massacres, including people with the same given name and surname(s). Thus, is not always clear in our dataset whether two records listing the same victim name, place, and date correspond to multiple reports of the same victim, or to family members. Importantly, match uncertainty is not incorporated into model uncertainty in the same way as other forms of uncertainty. We believe this is a reasonable choice, since match uncertainty cannot be quantified and is probably small.
} 
four datasets. After merging duplicated records, the total number of unique cases in our data was 20,048, denoted as $n_{*}^{i}$ for each stratum $i$.

Table 1: $\quad$ Summary of inclusion patterns

\begin{tabular}{llllll}
\hline In CDHES & In El Rescate & In UNTC & In UNTC-2 & Inclusion pattern & No. w/ this pattern \\
\hline 0 & 0 & 0 & 0 & 0000 & NA \\
0 & 0 & 0 & 1 & 0001 & 6057 \\
0 & 0 & 1 & 0 & 0010 & 4461 \\
0 & 0 & 1 & 1 & 0011 & 927 \\
0 & 1 & 0 & 0 & 0100 & 4238 \\
0 & 1 & 0 & 1 & 0101 & 1130 \\
0 & 1 & 1 & 0 & 0110 & 127 \\
0 & 1 & 1 & 1 & 0111 & 122 \\
1 & 0 & 0 & 0 & 1000 & 1828 \\
1 & 0 & 0 & 1 & 1001 & 459 \\
1 & 0 & 1 & 0 & 1010 & 87 \\
1 & 0 & 1 & 1 & 1011 & 67 \\
1 & 1 & 0 & 0 & 1100 & 156 \\
1 & 1 & 0 & 1 & 1101 & 314 \\
1 & 1 & 1 & 0 & 1110 & 26 \\
1 & 1 & 1 & 1 & 1111 & 49 \\
\hline
\end{tabular}

\subsection{Stratification}

For our purposes, a stratum is a subset of the data defined by a covariate or set of covariates; a stratification scheme is the rule or set of rules used to create mutually exclusive subsets of the data. Stratification schemes might include, for example, 'subset by year,' 'subset by department,' or 'subset by department and year. ${ }^{8}$ Stratification allows analysts to estimate variation in violence, an important substantive advantage. Methodologically, stratification is vital for reducing capture heterogeneity, particularly where the covariates used to define the strata are thought to be associated with changes in capture probability (i.e., in this case, changes in reporting dynamics). However, the set of possible stratification schemes is limited by missing data on a variety of covariates.

Table 2 presents each of the spatial and temporal stratification schemes for which we produced estimates, as well as three custom stratification schemes that mix multiple types of mutually exclusive strata. Not shown in Table 2 are the nine spatiotemporal stratification schemes produced by intersecting spatial and temporal strata. (For example, the intersection of 14 strata defined by the department and 13 strata defined by the year

\footnotetext{
${ }^{8}$ It is possible to stratify on non-spatiotemporal covariates (e.g., perpetrating group, victim characteristics); however, we focus here on estimating variation in violence over time and space.
} 
is the $14 \times 13=182$ department-year strata.) Custom stratification scheme multi-2 is shown alongside a single-type spatiotemporal stratification scheme in Figure 3.

Table 2: $\quad$ Stratification schemes

\begin{tabular}{|c|c|c|c|c|}
\hline $\begin{array}{l}\text { Stratification } \\
\text { scheme }\end{array}$ & Type & Label & $\begin{array}{l}\text { Total } \\
\text { strata }\end{array}$ & Description \\
\hline Department & Spatial & dept & 14 & Each department a stratum. \\
\hline Region & Spatial & re & 4 & $\begin{array}{l}\text { A west-to-east stratification scheme. West: Ahuachapán, } \\
\text { Sonsonate, and Santa Ana; West Central: La Libertad, } \\
\text { Chalatenango, San Salvador, and Cuscatlán; East Central: } \\
\text { Cabañas, San Vicente, La Paz, and Usulután; East: San } \\
\text { Miguel, La Union, and Morazán. }\end{array}$ \\
\hline Region-2 & Spatial & re2 & 5 & $\begin{array}{l}\text { Retains West and East categories from above but splits } \\
\text { the central part of the country into: San Salvador Region: } \\
\text { San Salvador, Cuscatlán, and La Libertad; North Central: } \\
\text { Chalatenango and Cabañas; and South Central: La Paz, } \\
\text { San Vicente, and Usulután. }\end{array}$ \\
\hline Region-3 & Spatial & re2 & 7 & $\begin{array}{l}\text { Groups of two neighboring depts: Ahuachapán and } \\
\text { Sonsonate; Santa Ana and Chalatenango; La Libertad and } \\
\text { San Salvador; Cuscatlán and Cabañas; La Paz and San } \\
\text { Vicente; Usulután and San Miguel, Morazán and La Union. }\end{array}$ \\
\hline Semester & Temporal & yr.sm & 26 & Each semester for all years: 1980 s1, 1980s2[...] \\
\hline Year & Temporal & yr & 13 & Each year: $1980,1981,1982[\ldots]$ \\
\hline Period & Temporal & $\mathrm{pd}$ & 2 & $\begin{array}{l}\text { 1980-1983, 1984-1992. Major changes in both state and } \\
\text { FMLN strategies in approximately } 1984 \text { may have been } \\
\text { associated with reporting changes. }\end{array}$ \\
\hline Period-3 & Temporal & $\mathrm{pd} 3$ & 4 & 1980-1982, 1983-1985, 1986-1988, 1989-1992. \\
\hline Period-4 & Temporal & $\mathrm{pd} 4$ & 2 & $\begin{array}{l}\text { 1980-1985, 1986-1992. An alternative specification to } \\
\text { Period, above. Here the change in reporting is assumed to } \\
\text { be associated with stalemate, rather than strategy change. }\end{array}$ \\
\hline Years-custom & $\begin{array}{l}\text { Multi-type } \\
\text { temporal }\end{array}$ & years.custom & 15 & $\begin{array}{l}\text { Semesters } 1980-1982 \text { ( } 6 \text { strata), years } 1983-1990 \\
\text { (8 strata), and the 1991-1992 period ( } 1 \text { stratum). }\end{array}$ \\
\hline Multi-1 & $\begin{array}{l}\text { Multi-type } \\
\text { spatio- } \\
\text { temporal }\end{array}$ & multi-1 & 44 & $\begin{array}{l}\text { Multiple spatial, temporal, and spatiotemporal stratum } \\
\text { types. }\end{array}$ \\
\hline Multi-2 & $\begin{array}{l}\text { Multi-type } \\
\text { spatio- } \\
\text { temporal }\end{array}$ & multi-2 & 20 & $\begin{array}{l}\text { Multiple spatial, temporal, and spatiotemporal stratum } \\
\text { types. }\end{array}$ \\
\hline
\end{tabular}


Hoover Green \& Ball: Civilian killings and disappearances during civil war in El Salvador (1980-1992)

\section{Figure 3: $\quad$ Stratifications underlying two global sums}

\begin{tabular}{|c|c|c|c|c|c|c|c|c|c|c|c|c|c|}
\hline \multicolumn{14}{|c|}{ Stratification scheme re3.pd } \\
\hline & 1980 & 1981 & 1982 & 1983 & 1984 & 1985 & 1986 & 1987 & 1988 & 1989 & 1990 & 1991 & 1992 \\
\hline Sonsonate & \multirow{2}{*}{\multicolumn{4}{|c|}{ Sonsonate-Ahuachapán, 1980-1983 }} & \multirow{2}{*}{\multicolumn{9}{|c|}{$\begin{array}{l}\text { Sonsonate-Ahuachapán, 1984-1992 (inadequate; does not } \\
\text { contribute to sum) }\end{array}$}} \\
\hline Ahuachapán & & & & & & & & & & & & & \\
\hline San Salvador & \multirow{2}{*}{\multicolumn{4}{|c|}{ La Libertád-San Salvador, 1980-1983 }} & \multirow{2}{*}{\multicolumn{9}{|c|}{ La Libertád-San Salvador, 1984-1992 }} \\
\hline La Libertad & & & & & & & & & & & & & \\
\hline Santa Ana & \multirow{2}{*}{\multicolumn{4}{|c|}{ Santa Ana-Chalatenango, 1980-1983 }} & \multirow{2}{*}{\multicolumn{9}{|c|}{ Santa Ana-Chalatenango, 1984-1992 }} \\
\hline Chalatenango & & & & & & & & & & & & & \\
\hline Cuscatlán & \multirow{2}{*}{\multicolumn{4}{|c|}{ Cuscatlán-Cabañas, 1980-1983 }} & \multirow{2}{*}{\multicolumn{9}{|c|}{ Cuscatlán-Cabañas, 1984-1992 }} \\
\hline Cabañas & & & & & & & & & & & & & \\
\hline San Vicente & \multirow{2}{*}{\multicolumn{4}{|c|}{ San Vicente-La Paz, 1980-1983 }} & \multirow{2}{*}{\multicolumn{9}{|c|}{ San Vicente-La Paz, 1984-1992 }} \\
\hline La Paz & & & & & & & & & & & & & \\
\hline Usulután & \multirow{2}{*}{\multicolumn{4}{|c|}{ Usulután-San Miguel, 1980-1983 }} & \multirow{2}{*}{\multicolumn{9}{|c|}{ Usulután-San Miguel, 1984-1992 }} \\
\hline San Miguel & & & & & & & & & & & & & \\
\hline Morazán & \multirow{2}{*}{\multicolumn{4}{|c|}{ Morazán-La Union, 1980-1983 }} & \multirow{2}{*}{\multicolumn{9}{|c|}{ Morazán-La Union, 1984-1992 }} \\
\hline La Union & & & & & & & & & & & & & \\
\hline
\end{tabular}

\begin{tabular}{|c|c|c|c|c|c|c|c|c|c|c|c|}
\hline \multicolumn{12}{|c|}{ Stratification scheme multi-2 } \\
\hline & 1980 & 1981 & 1982 & 1983 & 1984 & 1985 & \begin{tabular}{|l|l|l|}
1986 & 1987 & 1988 \\
\end{tabular} & 1989 & 1990 & 1991 & 1992 \\
\hline Sonsonate & \multirow{3}{*}{\multicolumn{2}{|c|}{ West, 1980-1981 }} & \multirow{3}{*}{\multicolumn{2}{|c|}{ West, 1982-1983 }} & \multirow{3}{*}{\multicolumn{7}{|c|}{ West, 1984-1992 }} \\
\hline Ahuachapán & & & & & & & & & & & \\
\hline Santa Ana & & & & & & & & & & & \\
\hline La Libertad & \multirow{2}{*}{\multicolumn{4}{|c|}{ La Libertád-San Salvador, 1980-1983 }} & \multirow{2}{*}{\multicolumn{2}{|c|}{$\begin{array}{l}\text { La Libertád- } \\
\text { San Salvador, } \\
\text { 1984-1985 }\end{array}$}} & \multirow{2}{*}{\begin{tabular}{|l} 
La Libertád-San \\
Salvador, 1986- \\
1988
\end{tabular}} & \multirow{2}{*}{\multicolumn{4}{|c|}{$\begin{array}{l}\text { La Libertád-San Salvador, } \\
\text { 1989-1992 }\end{array}$}} \\
\hline San Salvador & & & & & & & & & & & \\
\hline Chalatenango & \multicolumn{3}{|c|}{ Chalatenango, 1980-1982 } & Chalatenar & 0,1983 & 1985 & \multicolumn{5}{|c|}{ Chalatenango, 1986-1992 } \\
\hline Cuscatlán & \multirow{2}{*}{\multicolumn{4}{|c|}{ Cuscatlán-Cabañas, 1980-1983 }} & \multirow{2}{*}{\multicolumn{7}{|c|}{ Cuscatlán-Cabañas, 1984-1992 }} \\
\hline Cabañas & & & & & & & & & & & \\
\hline San Vicente & \multirow{3}{*}{\multicolumn{2}{|c|}{$\begin{array}{l}\text { South Central, } \\
1980-1981\end{array}$}} & \multirow{2}{*}{\multicolumn{2}{|c|}{$\begin{array}{l}\text { La Paz-San Vicente, } \\
1982-1983\end{array}$}} & \multicolumn{7}{|c|}{ San Vicente, 1984-1992 } \\
\hline La Paz & & & & & \multicolumn{7}{|c|}{ La Paz, 1984-1992 } \\
\hline Usulután & & & \multicolumn{2}{|c|}{ Usulután, 1982-1983 } & \multicolumn{7}{|c|}{ Usulután, 1984-1992 } \\
\hline San Miguel & \multirow{3}{*}{\multicolumn{4}{|c|}{ East, $1980-1983$}} & \multirow{3}{*}{\multicolumn{7}{|c|}{ East, 1984-1992 }} \\
\hline Morazán & & & & & & & & & & & \\
\hline La Union & & & & & & & & & & & \\
\hline
\end{tabular}

In general, our priorities for developing custom stratification schemes include:

- Minimizing the Hartigan dip test statistic (Hartigan and Hartigan 1985), to decrease the probability that our strata contain highly heterogenous capture probabilities. (See 'Directions for future research,' below, for further discussion of this choice);

- Maximizing within-stratum sample sizes to more closely approximate the assumption that the distribution of observations over cells in each stratum follows the multinominal distribution;

- Maximizing the number of cells (inclusion patterns) with values greater than zero to 
maximize the number of interaction terms that can be considered when generating estimates;

- Maximizing the total number of strata employed in the sum, to produce disaggregated estimates that can more easily be used to examine patterns and causes of violence. Without disaggregation, we cannot consider patterns of violence over time or space.

Because these goals directly conflict with one another, in calculating global sums over strata, we test several single-type and custom stratification schemes against one another. These results are presented below.

\subsection{Estimation procedure}

A separate MSE model is fit for each stratum in a given stratification scheme. Here, we describe the general process of estimation for any stratum. Several approaches have been suggested; here, we adopt log-linear modeling, as first explicated by Bishop, Fienberg, and Holland (1975), and described by Lum et al. (2013). That is, the natural log of the number of episodes counted in a given inclusion pattern is modeled as a function of the number of episodes counted in other inclusion patterns. Our key unknown value - the number of cases not recorded in any list, i.e., those with inclusion pattern 0000 - is the $y$ intercept of the model (exponentiated because the model is in the log scale).

With four data sources, there are 15 inclusion patterns and tens of thousands of possible log-linear models. Rather than selecting among these models a priori or using brute force (fitting all possible models) we use Bayesian model averaging over the decomposable graphical models (Madigan and York 1997), implemented in $R$ by Johndrow, Lum, and Ball (2015) in the $R$ package DGA (for decomposable graphs approach). ${ }^{9}$ DGA calculates all log-linear models that can be represented as decomposable graphical models, of which for four systems there are 61, a reduction from tens of thousands of log-linear models. $^{10}$

DGA estimates the posterior probabilities of the estimates for all 61 decomposable graphical models, over a wide range of plausible numbers of unrecorded cases. We chose to estimate the probabilities for values of 1 to 20 times the total number of recorded cases in the stratum $\left(n_{*}^{i}\right)$ because we believe it is unlikely that there are more than 20 times more unobserved cases than observed cases for any stratum. The sum of the weights over models for each plausible number of unrecorded cases yields the posterior probability of

\footnotetext{
${ }^{9}$ Note that the package's title is, in point of fact, 'dga' (lower case), but for readability we use DGA in this text.

${ }^{10}$ Darroch, Lauritzen, and Speed (1980: 17, Table 3) compare the number of total log-linear models to the number of hierarchical, graphical, and decomposable graphical models, given $p$ lists, where $p \leq 5$.
} 
that estimated number of unobserved killings; together, this vector of estimates yields the posterior probabilities of each stratum's estimate.

In their article introducing DGA, Madigan and York (1997) advocate the use of informative priors where there is a theoretical expectation about the level of underreporting. In this case, while we expect the level of under-reporting to vary significantly across strata, we employ a combination of 'expert guesses' and previous MSE work to build informative priors about the total number of deaths. We also test these informative priors against 'baseline' uninformative priors.

We first created baseline estimates using the DGA package's default prior distribution, in which the probability of each value (of unobserved deaths) is proportional to $\frac{1}{n_{00000}}$. (For this analysis, we set the maximum value of unobserved deaths to be 20 times the number of observed deaths in each stratum.) We also estimated models with a variety of lognormal prior distributions. The lognormal is an attractive distribution for this purpose because it places most weight in one area but has a 'long right tail' to allow for significant variation in under-reporting. Experts on the conflict in El Salvador tend to use the number 75,000, although it is not derived from a statistical estimate (e.g., Stanley 1996; Wood 2003; Viterna 2013). A previous MSE estimate using a frequentist approach (Hoover Green 2011) estimated approximately 80,000 deaths. In order to represent our prior belief that the true number of deaths is approximately 75,000, and because we have approximately 20,000 reported deaths, we chose parameters that center the maximum prior probability at $3.75 \times n_{*}^{i}$. A comparison of the prior probabilities for the noninformative default prior and our informative lognormal prior is shown in Figure $4 .^{11}$

\footnotetext{
11 The parameters for the lognormal distribution are $\ln (X) \sim \mathcal{N}\left(\mu, \sigma^{2}\right)$, with $\mu=0.7$ and $\sigma=0.6$. That is, the natural $\log$ of the prior distribution employed in these analyses, $X$, is a normal distribution with mean 0.7 and standard deviation 0.6, over the interval from 1 to 20 times the observed value.
} 
Figure 4: $\quad$ Prior probabilities using default and Lognormal $(0.7,0.6)$ distributions

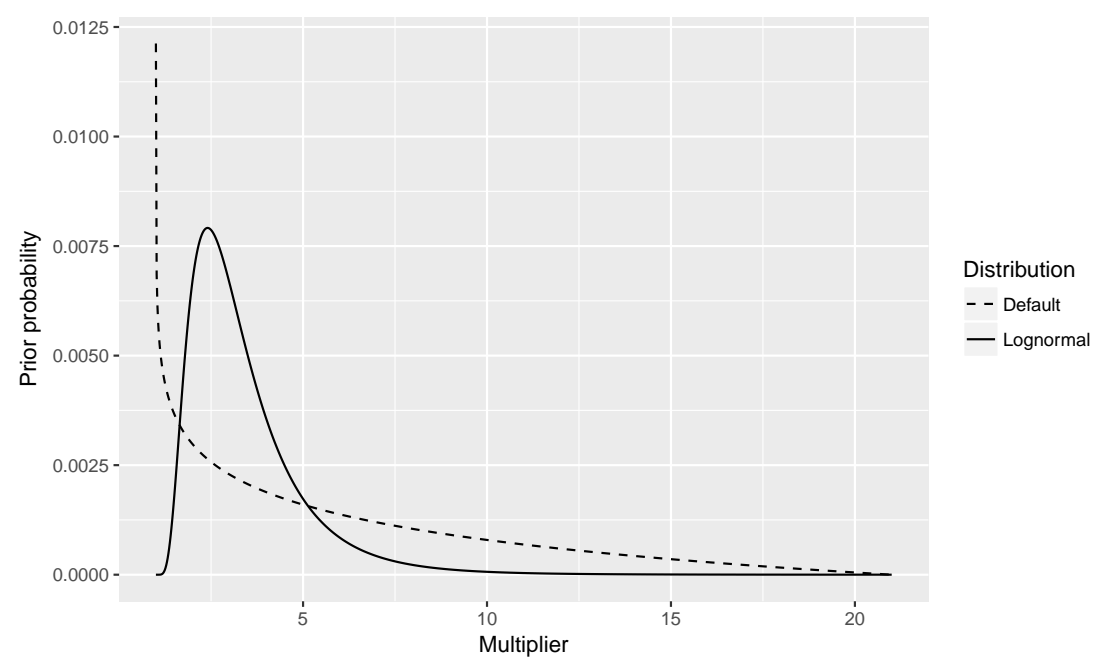

These are different prior distributions, and consequently we considered whether the choice of prior drives our substantive results. We found that changing the prior distribution from the default prior distribution to our informative lognormal prior results in different point estimates in only about $10 \%$ of all strata. That is, in general, it is data rather than priors that drive these estimates. The major benefit of our chosen prior distribution is that it reduces slightly the credible intervals of our estimates.

Finally, for each stratum, we considered several related dimensions of stratum quality, including (1) the size of the stratum (number of observations included in any cell), (2) the top-weighted model, (3) the modality of the posterior distribution as measured by the Hartigan dip test (Hartigan and Hartigan 1985), (4) the number of zero cells in the contingency table, and (5) the difference between stratum estimates derived with a noninformative prior and those calculated with our preferred lognormal prior. ${ }^{12}$ To be regarded as adequate and employed in the analysis, strata must (1) have sufficient data to fit a model ( $N \gtrsim 250)$ and must not (2) place all or nearly all weight on the fully

\footnotetext{
${ }^{12}$ For readers who may be unfamiliar with it, the Hartigan dip test "measures multimodality in a sample by the maximum difference, over all sample points, between the empirical distribution function, and the unimodal distribution function that minimizes that maximum difference" (Hartigan and Hartigan 1985: 70). Higher dip test values indicate clearer multimodality and are associated with lower p-values, where the p-value of a given dip test measures, in effect, the likelihood that the distribution is unimodal. For more information on the dip test and its interpretation, see the discussion at https://stats.stackexchange.com/questions/156808/interpretation-ofhartigans-dip-test.
} 
saturated model, or (3) be clearly multimodal. (We revisit this definition of adequate in the discussion section.) One example of an inadequate stratum, the year 1981, is shown in Figure 5.

Figure 5: $\quad$ Posterior probability of estimated total killings for 1981

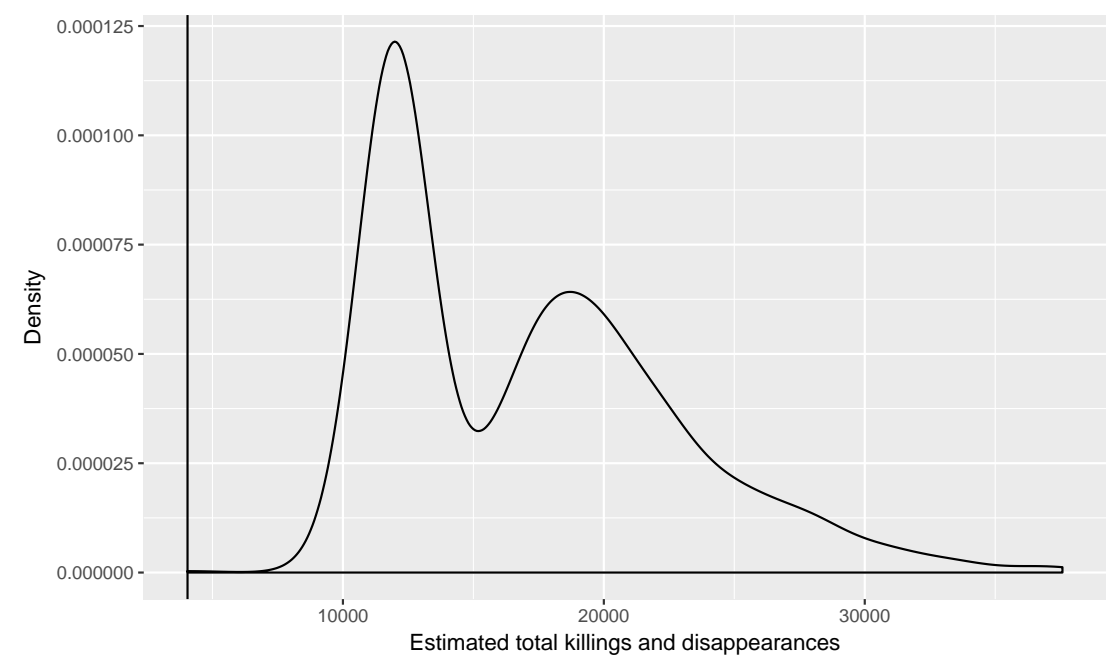

The posterior probability for 1981 shows two distinct modes, demonstrating that there are two models (or two groups of models) with substantial weight, but which produce quite different estimates. Several factors might underlie a multimodal posterior distribution. One possibility is capture heterogeneity (defined above). In the presence of capture heterogeneity, different models may make quite different estimates because each model includes some subset of the possible log-linear interactions, and no model may include all the iterations. Not all capture heterogeneity can be identified by observing the modality of the posterior, and not all multimodality is the result of capture heterogeneity. However, when the posterior is multimodal, we deem it inadequate for use. Since Sekar and Deming (1949), when analysts suspect the presence of capture heterogeneity, they have subdivided the stratum in the hope that the heterogeneity is correlated with the covariate(s) used for the subdivision. The goal is that the new, smaller strata have more uniform probabilities of observation. That is the approach adopted here; note that in the stratifications presented below, 1981 is divided by semester, region, or department. 


\section{Results}

We found adequate estimates for 497 overlapping strata, stratifying on department, multidepartment region, year, multi-year period, perpetrator type, and various combinations of these. These results allow us to examine patterns of violent mortality over time and space, and to sum across strata to achieve a global estimate of deaths. Importantly, there was no individual stratum type (e.g., years, departments, department-years) for which estimates for all strata (e.g., all years, all departments, all department-years) were adequate. For example, adequate estimates were possible for each year in 1980-1990, but for both 1991 and 1992, data were too sparse, or estimates were too poor-fitting or multimodal, to allow for individual-year estimates. Estimates were adequate for 13 of 14 departments. Among 182 department-years (14 departments $\times 13$ years), we found adequate estimates for 30 . Thus, to estimate the global sums reported below, we rely on mixtures of stratum types. Below, we discuss spatial and temporal variation, and then present our global estimates.

\subsection{Spatial variation}

Recall from above that our four data sources disagreed about both the total magnitude of violence and its distribution across space. CDHES data placed the highest per-capita violence in San Salvador department, where it recorded approximately 1.76 episodes of lethal violence per 1000 residents of the department (according to 1981 population figures by department in the Statesman's Yearbook [1988]). ${ }^{13}$ El Rescate's data showed the highest prevalence of lethal violence in Cuscatlán department, at about 1.12 episodes per 1000 residents. Direct data to the Truth Commission tell quite a different story: In these data, Chalatenango appears to be the most affected department, with a prevalence of about 0.46 episodes of lethal violence per 1000 residents. And indirect reports to the Truth Commission place the highest burden of lethal violence in San Vicente department, estimating about 0.86 episodes per 1000 residents.

It is therefore important to ask how (whether) these data sources - which together likely account for only a minority of the total burden of lethal violence - line up with MSE estimates. Table 3 and Figure 6 show MSE estimates by department. Figure 5 represents MSE estimates by department, including uncertainty, graphically. The fill color indicates

\footnotetext{
${ }^{13}$ In reporting the prevalence of violence per 1000 residents, it is necessary to first determine the population of each department for the relevant period. This is a difficult task. El Salvador conducted no official census between 1971 and 1992, and during the war (particularly its extremely violent early years) a significant proportion of the population was displaced, either internally or externally. Thus, sources on departmental populations in the 1980's, and particularly the early 1980's (the time of most significant population movement and violence) frequently disagree. For the estimates here we used Statesman's Yearbook information (1988, citing 1981 data), but results were not altered substantially when we used other departmental population estimates.
} 
Hoover Green \& Ball: Civilian killings and disappearances during civil war in El Salvador (1980-1992)

the point estimate for that department, while the gridded dots represent the upper and lower bounds of the $95 \%$ credible interval. ${ }^{14}$ More contrast denotes more uncertainty.

Table 3: $\quad$ MSE estimates by department

\begin{tabular}{llllcl}
\hline Department & $\begin{array}{l}\text { Population } \\
(\mathbf{1 0 0 0 s )})\end{array}$ & $\begin{array}{l}\text { Known } \\
\text { lethal } \\
\text { violence }\end{array}$ & $\begin{array}{l}\text { MSE estimate } \\
\mathbf{( 9 5 \% ~ C I )}\end{array}$ & $\begin{array}{l}\text { Est. prevalence } \\
\text { per 1000 }\end{array}$ & Est. capture rate \\
\hline Ahuachapán & 241 & 414 & $1775(710,3725)$ & $7.37(2.95,15.46)$ & $0.23(0.11,0.58)$ \\
Cabañas & 180 & 840 & $2198(1864,2633)$ & $12.21(10.36,14.63)$ & $0.38(0.32,0.45)$ \\
Chalatenango & 236 & 2702 & $12459(5496,16974)$ & $52.79(23.29,71.92)$ & $0.22(0.16,0.49)$ \\
Cuscatlán & 204 & 1880 & $8701(6880,11274)$ & $42.65(33.73,55.26)$ & $0.22(0.17,0.27)$ \\
La Libertad & 389 & 1147 & $6810(4643,10366)$ & $17.51(11.94,26.65)$ & $0.17(0.11,0.25)$ \\
La Paz & 250 & 742 & $3844(2845,5384)$ & $15.38(11.38,21.54)$ & $0.19(0.14,0.26)$ \\
La Union & NA & NA & NA & NA & NA \\
Morazán & 215 & 1734 & $3287(2987,4957)$ & $15.29(13.89,23.06)$ & $0.53(0.35,0.58)$ \\
San Miguel & 434 & 581 & $2326(1713,3750)$ & $5.36(3.95,8.64)$ & $0.25(0.15,0.34)$ \\
San Salvador & 980 & 5373 & $27107(19632,37988)$ & $27.66(20.03,38.76)$ & $0.2(0.14,0.27)$ \\
San Vicente & 207 & 1961 & $9961(7205,18832)$ & $48.12(34.81,90.98)$ & $0.2(0.1,0.27)$ \\
Santa Ana & 445 & 1079 & $6967(1729,15530)$ & $15.66(3.89,34.9)$ & $0.15(0.07,0.62)$ \\
Sonsonate & 322 & 391 & $1337(793,2870)$ & $4.15(2.46,8.91)$ & $0.29(0.14,0.49)$ \\
Usulután & 400 & 1103 & $4577(3591,6462)$ & $11.44(8.98,16.16)$ & $0.24(0.17,0.31)$ \\
\hline
\end{tabular}

Figure 6: $\quad$ Killings and disappearances by department, MSE estimates

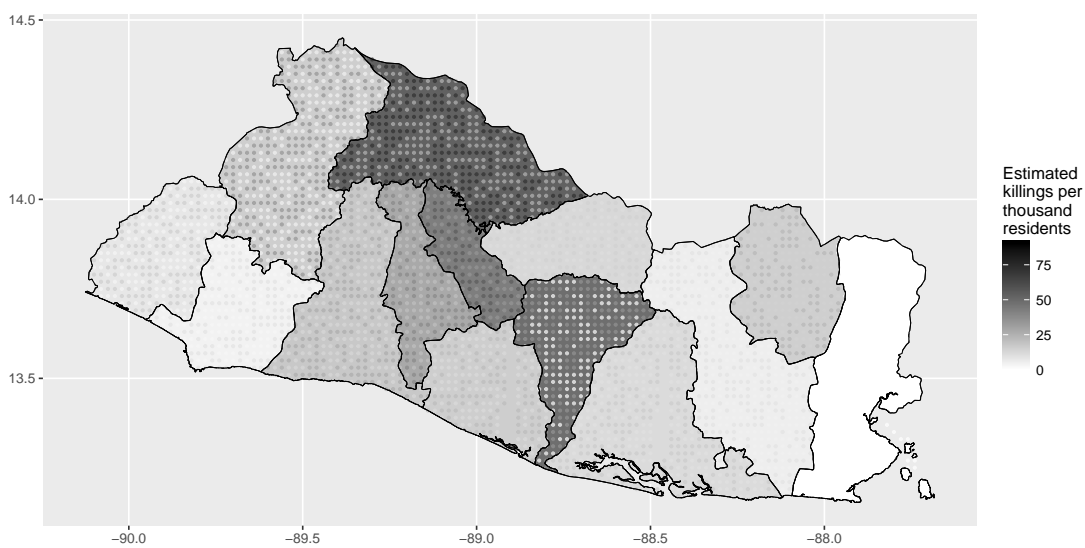

\footnotetext{
14 More specifically, for each grid point, the function that creates this visualization chooses randomly between the color corresponding to the upper bound and the color corresponding to the lower bound. Dots do not indicate geography or density.
} 
We estimate that the departments with the highest burden of violence are Chalatenango and San Vicente. We estimate that, for every 1000 department residents in 1980, about $52.79(23.29,71.92)$ people died in Chalatenango, and about $48.12(34.81,90.98)$ people died in San Vicente, over the course of the war. ${ }^{15}$ While Chalatenango was known to have been an epicenter of violence, the extremely high burden of violence in San Vicente may surprise some analysts of the Salvadoran conflict. ${ }^{16}$ Another potentially surprising finding is the relatively low estimated burden of mortality in the department of Morazán. Morazán was the stronghold of the FMLN's most militarist faction and a major target of government raiding and massacres in the war's early years, including the notorious massacre at El Mozote (Danner 1993; Binford 2016). Morazán ranked among the top five most violent departments per capita according to each dataset, as well as the summed raw data - but it is not among the most violent departments according to MSE estimates. Perhaps the scrutiny resulting from El Mozote and other massacres led to much higher capture rates in Morazán than elsewhere.

More generally, the estimated capture rate (or, equivalently, the 'reporting rate,' the proportion of estimated deaths reported in one or more datasets) varies substantially from department to department, from $0.17(0.11,0.25)$ in La Libertad department to $0.53(0.35$, 0.58) in Morazán. In a reversal that mirrors the results for Morazán, La Libertad is not among the most violent departments in any raw dataset but ranks fifth most violent according to MSE estimates.

In Table 4, we show Spearman rank correlations between raw data sources and MSE estimates across the 13 departments for which adequate MSE estimates were possible. High correlations would imply that the various data sources and the estimates agree on the ranking of departments by levels of violence, while low correlations would imply the opposite. The results suggest fairly high, but far from perfect, correlation between estimated totals and individual datasets - at least where ranking departments by estimated per-capita violence is concerned.

\footnotetext{
${ }^{15}$ Note that not all victims in a given department were residents of that department. Our data reflect the location of the killing, not the victim's place of residence.

16 This finding accords with some newer accounts of the civil war in San Vicente (e.g., Galeas and Ayala 2008), which document the actions of a rogue FMLN commander in San Vicente who ordered many (hundreds or perhaps thousands) of recruit and civilian killings before being executed himself on the orders of the high command.
} 
Table 4: $\quad$ Rank correlations between raw data and MSE estimates, by department

\begin{tabular}{llllll}
\hline & CDHES & El Rescate & UNTRC & UNTRC-2 & MSE \\
\hline CDHES & 1 & 0.68 & 0.45 & 0.7 & 0.6 \\
EI Rescate &. & 1 & 0.63 & 0.83 & 0.76 \\
UNTRC &. &. & 1 & 0.82 & 0.69 \\
UNTRC-2 & $\cdot$ &. &. & 1 & 0.74 \\
MSE &. & $\cdot$ &. &. & 1 \\
\hline
\end{tabular}

\subsection{Temporal variation}

How did violence vary over time? As with spatial variation, our raw datasets disagree significantly about which was the most (lethally) violent year in El Salvador's civil war. As shown above in Figure 1, CDHES data peak in 1982 (but show similar numbers of killings in 1980). El Rescate data peak in 1983, UNTC data in 1980, and UNTC-2 data in 1981. We estimate that the most violent year by far was 1982, when 22,904 (12897, 37000) Salvadorans were killed. These results are presented in Table 5 and Figure $7 .{ }^{17}$ More broadly - and similarly to the case of Guatemala (cf. Ball 2000; Davenport and Ball 2002) - variation in estimated yearly violence dwarfs yearly variation from any individual dataset, as well as yearly variation in the sum of all known cases.

Table 5: $\quad$ MSE estimates by year

\begin{tabular}{llll}
\hline Year(s) & Known killings & MSE estimate $(\mathrm{Cl})$ & Est. capture rate \\
\hline 1980 & 4155 & $12404(10612,15488)$ & $0.33(0.27,0.39)$ \\
1981 & 3907 & $10792(9787,15955)$ & $0.36(0.24,0.4)$ \\
1982 & 3679 & $22904(12897,37000)$ & $0.16(0.1,0.29)$ \\
1983 & 2325 & $9846(6023,19645)$ & $0.24(0.12,0.39)$ \\
1984 & 1333 & $4712(4021,6047)$ & $0.28(0.22,0.33)$ \\
1985 & 820 & $3318(2307,5220)$ & $0.25(0.16,0.36)$ \\
1986 & 639 & $2292(1665,3109)$ & $0.28(0.21,0.38)$ \\
1987 & 560 & $1444(1149,1990)$ & $0.39(0.28,0.49)$ \\
1988 & 682 & $1988(1528,2769)$ & $0.34(0.25,0.45)$ \\
1989 & 802 & $2755(2184,3593)$ & $0.29(0.22,0.37)$ \\
1990 & 493 & $1742(1343,2406)$ & $0.28(0.2,0.37)$ \\
$1991-1992$ & 217 & $778(537,1183)$ & $0.28(0.18,0.4)$ \\
\hline
\end{tabular}

\footnotetext{
${ }^{17}$ Note that, because data were too sparse to calculate individual year estimates for 1991-1992, we calculate a single estimate for this two-year period, which is not shown in Figure 7.
} 
Figure 7: $\quad$ Lethal violence by year, raw data and MSE estimates

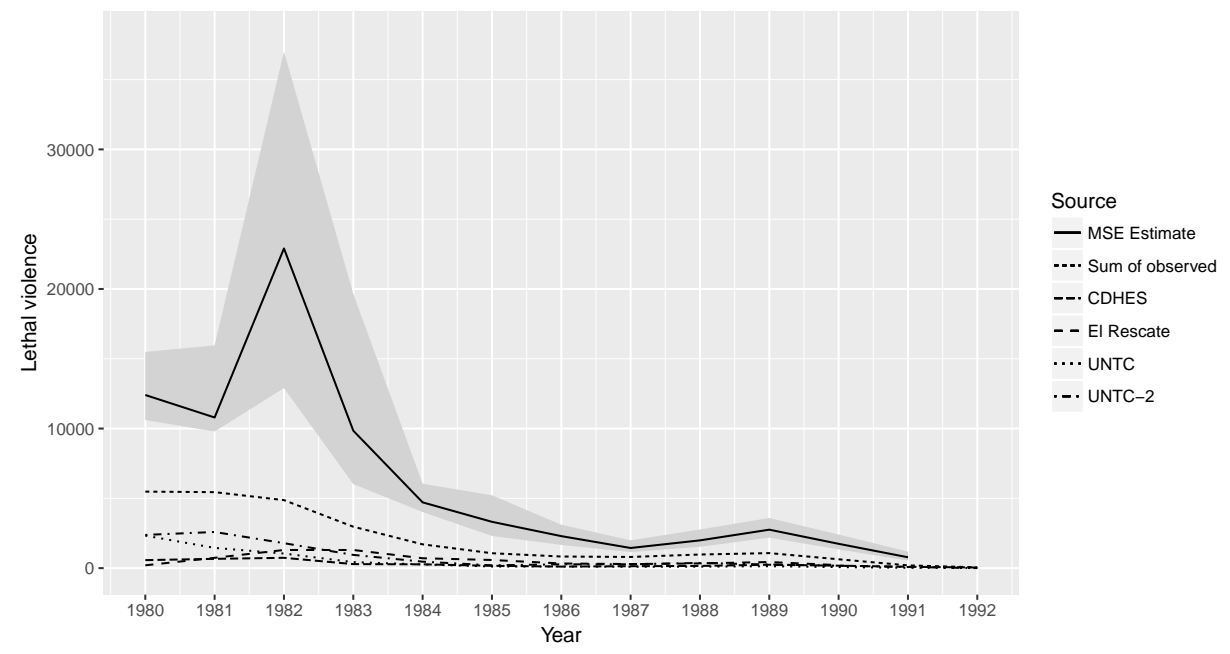

As with department-specific estimates, we also ask whether and to what extent yearly estimates from individual data sources represent the 'facts on the ground' in El Salvador. In terms of rank ordering (Spearman) correlation, UNTC data are very highly correlated with MSE estimates. Notably, three of the four datasets (excepting El Rescate) are more strongly correlated with MSE estimates over time than over space.

Table 6: $\quad$ Rank correlations over years, raw data and MSE

\begin{tabular}{llllll}
\hline & CDHES & El Rescate & UNTC & UNTC-2 & MSE \\
\hline CDHES & 1 & 0.58 & 0.81 & 0.72 & 0.87 \\
EI Rescate &. & 1 & 0.56 & 0.53 & 0.65 \\
UNTC &. &. & 1 & 0.88 & 0.95 \\
UNTC-2 & $\cdot$ &. &. & 1 & 0.81 \\
MSE & $\cdot$ &. &. &. & 1 \\
\hline
\end{tabular}

\subsection{Global estimates}

While variation over time and space (and space $\times$ time) is an important research question, the key goal of this article is an estimate, with credible interval, of the total number of Salvadoran civilians killed or disappeared during the 1980-1992 period. An unstratified global estimate is possible, but not adequate, for several reasons, the most important of which is heterogeneity in the probability of capture. As we have seen, estimated capture 
rates varied significantly over both time and space, and this issue leads to a non-unimodal global estimate with an extraordinarily wide credible interval. We therefore prefer estimates based on sums over strata, as illustrated in Table 7 and Figure 8 and described below.

Table 7: $\quad$ MSE estimates: Sums across strata

\begin{tabular}{lllll}
\hline Stratum type(s) & $\begin{array}{l}\text { Known lethal } \\
\text { violence }\end{array}$ & MSE estimate (95\% Cl) & $\begin{array}{l}\text { Mean 0 cells } \\
\text { per stratum }\end{array}$ & $\begin{array}{l}\text { Prop. w/ } \\
\text { 0 cells }\end{array}$ \\
\hline multi-2 (20 strata) & 20,048 & $71,629(60,326,83,775)$ & 1.5 & 0.65 \\
multi-1 (43 strata) & 20,048 & $59,852(55,913,65,182)$ & 3.21 & 0.91 \\
re2.pd (10 strata) & 20,048 & $82,982(69,584,100,352)$ & 0.8 & 0.6 \\
re2.pd4 (10 strata) & 20,048 & $93,332(79,868,114,662)$ & 1.1 & 0.7 \\
re3.pd (14 strata) & 20,048 & $86,498(70,144,109,863)$ & 1.14 & 0.5 \\
dept (13 strata) & 19,945 & $93,036(78,533,109,605)$ & 1.31 & 0.69 \\
re3.pd4 (13 strata) & 19,915 & $105,692(87,530,124,411)$ & 1.23 & 0.54 \\
year (11 strata) & 19,831 & $95,056(68,507,118,833)$ & 0.36 & 0.27 \\
dp.pd (24 strata) & 19,698 & $68,822(61,283,90,301)$ & 2.17 & 0.83 \\
years.custom (15 strata) $)$ & 19,612 & $76,858(64,921,93,598)$ & 0.93 & 0.4 \\
re.pd3 (13 strata) & 19,579 & $101,982(86,932,122,889)$ & 1.54 & 0.54 \\
yr.sm (23 strata) & 19,451 & $72,200(61,065,87,369)$ & 1.78 & 0.65 \\
\hline
\end{tabular}

Figure 8: $\quad$ Posterior probabilities for sums across multiple stratifications

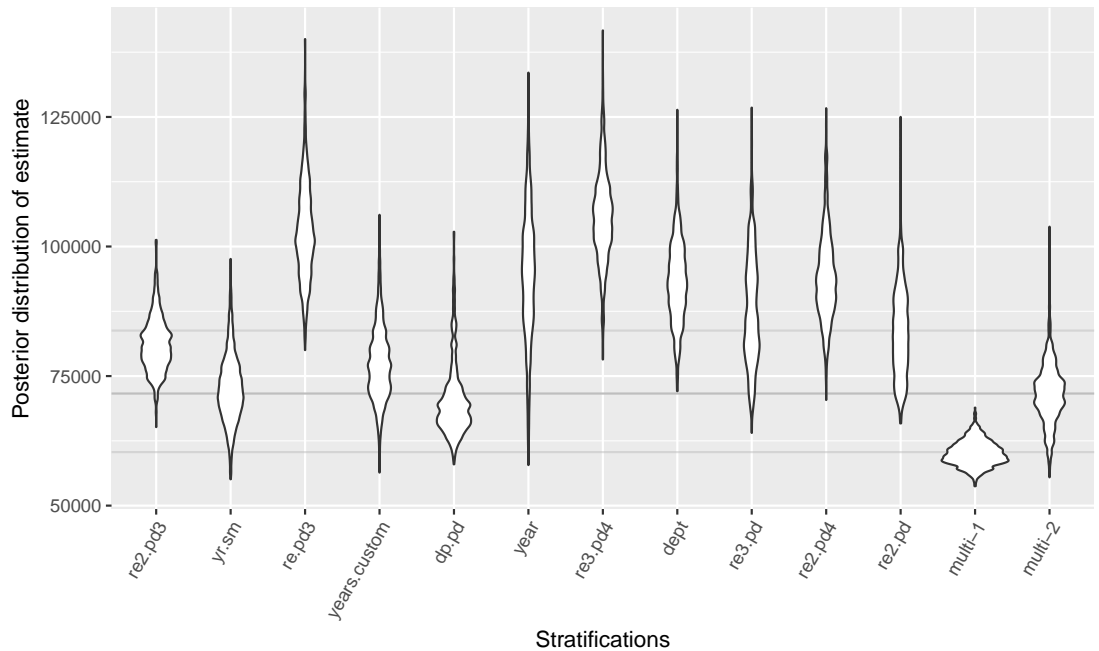




\subsubsection{Sums over strata}

We begin by discussing global sums implied by the spatial and temporal estimates discussed in the previous sections. Summing over the 13 adequate department strata (out of 14 total departments), we estimate a total of violent deaths. In Table 7 and Figure 8, this sum is labeled 'dept.' Temporal variation offers a greater number of stratification options. Stratifying by year (labeled 'year' in Table 7 and Figure 8) relies on an insufficient stratum (1981, as shown above in Figure 4), discards data from 1991 and 1992, and produces an extraordinarily wide credible interval: Semester-wise stratification (labeled 'yr.sm' in Table 6) yields an estimate of , and relies on no inadequate strata - but discards data from several strata due to sparseness. Combining three temporal stratum types (semesters of 1980-1982, years 1983-1990, and the 1991-1992 period, labeled 'years.custom'), we estimate violent deaths. Notably, credible intervals for all temporal estimates overlap the credible interval for the sum over departments, despite having no strata in common.

We then examine sums over mutually exclusive spatiotemporal strata. (In this context, 'mutually exclusive' means that each unique record is contained in only one stratum.) As described above, spatiotemporal strata are created using combinations of one of three spatial stratifications and one of three temporal stratifications (see Table 2). For example, in Table 7, the 're3.pd' sum indicates a sum over seven two-department regions, by two temporal periods (1980-1983, 1984, and later). Thus, $7 \times 2=14$ strata 'should' contribute to this global sum. However, one of the strata defined this way was inadequate; hence, 13 strata and 20,048 incidents contribute to the summed estimate for this stratification scheme, . Given four spatial and five temporal stratifications, twenty such spatiotemporal stratification schemes are theoretically possible. However, with the exception of the sum over years discussed above, we discard stratification schemes that rely on inadequate strata. We also discard stratification schemes that use less than $95 \%$ of observed killings, and those that use fewer than ten total strata. The remaining strata are shown in Table 7 and Figure 8.

Finally, we generate sums using custom stratification schemes. These sums include multiple stratum types (e.g., both department-periods and region-years) and, as noted above, are designed to balance our interest in decreasing the heterogeneity of capture probabilities with our interest in adequate estimates. The strata in these schemes include all 20,048 unique observations. Two such schemes, multi-1 and multi-2, are shown in Table 7 and Figure 8. Figure 9 shows the posterior probabilities of the summed estimates for multi-2. 
Figure 9: $\quad$ Posterior probability of estimated killings and disappearances in El Salvador, 1980-1991, for stratification multi-2

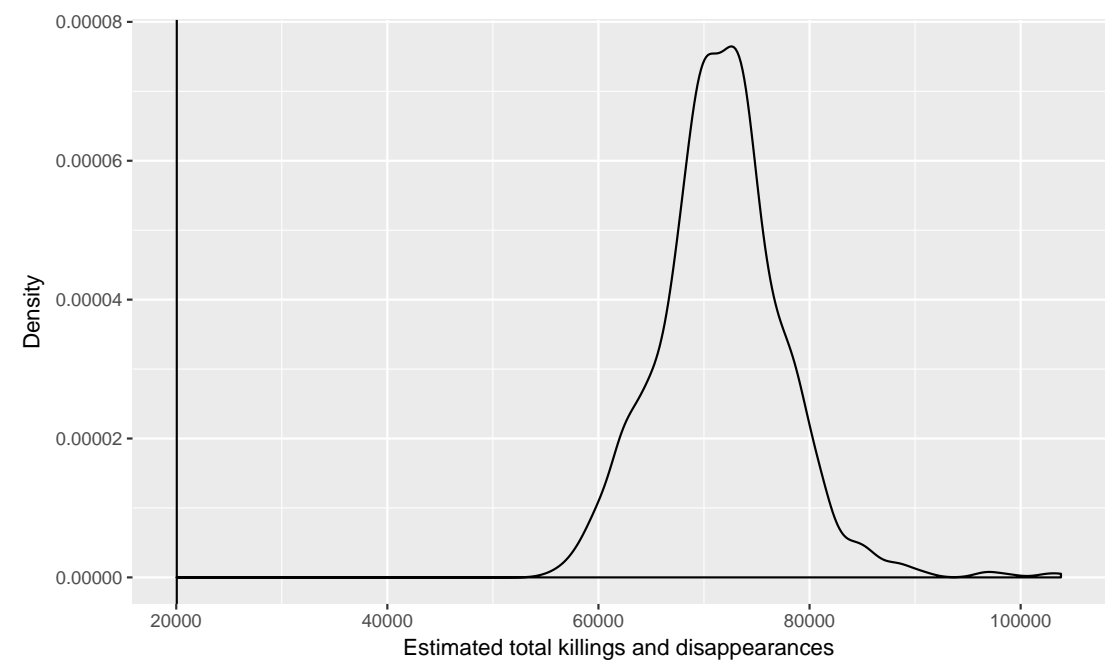

The multi-1 stratification was selected to maximize disaggregation by choosing the largest possible number of mutually exclusive strata for which adequate estimates were available. But multi-1 also has the highest level of sparsity among our global sums In multi-1, 41 of the 44 strata (93\%) include at least one zero cell, with a mean number of zero cells per stratum of about 3.23. It also includes several strata with small sample sizes, borderline multimodality, or significant disagreements between the informative and noninformative prior.

In comparison, multi-2 uses fewer strata than multi-1. But it features only a moderate proportion of strata with zero cells (0.65), and a low mean number of zero cells per stratum (1.50). In addition, multi-2 uses only strata that meet the criteria for adequacy discussed above, and in addition have moderate sample sizes, show unambiguous unimodality, and produce similar estimates over a range of prior distributions. When the distribution of the posterior is similar over a range of priors, our confidence in the estimate is greater because we interpret the posterior as depending less on the prior than on the data and the model. For this reason, while it is possible to make a case for some other global sums, multi-2 is the sum reported in, for example, the abstract and introduction to this article: $71,629(60,326,83,775)$. 


\section{Discussion}

From 20,048 unique reported cases of killing and disappearance during civil war in El Salvador, we estimate that the true number of killings and disappearances during the Salvadoran civil war was approximately $71,629(60,326,83,775)$. This estimate generally accords with 'expert guesses' by scholars and other observers. The overall estimates vary by the stratification, but all estimates' credible intervals overlap, increasing our confidence in these estimates. Moreover, all estimates agree that the true number of killings and disappearances during the Salvadoran civil war was significantly greater than the recorded number.

Estimates of variation in lethal violence, over time and space, are perhaps more surprising. The estimated prevalence of violence in rural San Vicente department was among the country's highest, although San Vicente has received less attention than other departments as a site of either battles or atrocities. 1982 emerged as considerably more lethal than any other year of the conflict; according to the yearly estimates in Table 4, nearly $30 \%$ of all killings and disappearances over the course of the war took place in 1982. These estimates will provide key context as Salvadorans grapple with the longterm consequences of the war, including the newly revitalized push to prosecute war crimes.

It is unlikely that these estimates will be the final word on mortality in the Salvadoran civil war. Multiple systems estimation, particularly where it requires summing over strata, presents some key questions for future researchers, particularly around issues of stratification for global estimation. Following Sekar and Deming's (1949) original recommendation, and in line with the goals of empirical research on political violence, our practice has been to divide data into the smallest possible strata with an acceptable number of zero cells in the inclusion pattern. Although we have followed this approach here, we now identify a number of questions for future research.

First, for a given stratum, multiple modes in the posterior distribution of $\hat{N}$ represent different estimates derived from different log-linear models. These differences may arise because the population being sampled in this stratum contains a mix of capture probabilities, as we proposed. Differences in capture probabilities affect list interactions, and consequently different log-linear models will arrive at different estimates of the unobserved killings. However, it is also possible that multimodality arises from stratum sizes that are too small (i.e., from overstratification). If the sample size is too small, there may be insufficient data to allow the cells of the $x_{i j k l}$ table to approximate the correct distribution to enable a reliable estimate of $x_{0000}$, the cell representing the unobserved killings. All else being equal, a smaller sample should result in higher variance; multimodality is one way to observe higher variance. If this is true, then our stratification does not adequately control for heterogeneity, and it may worsen the weakness of estimates in already too-small strata. 
A second issue associated with stratification is that, by creating and examining many candidate strata, we may find strata that appear to fit well by chance. This is similar to what Gelman and Loken (2013) call the 'garden of forking paths.' Another way to frame this problem is this: When we split a multi-modal stratum, the estimates of the new strata may have smaller variances than the original purely by chance. Any data-driven stratification approach may be affected by this problem. One way to address the issue in future research would be to test an initial, theory-driven set of candidate strata for capture heterogeneity, then split if (and, perhaps, only if) heterogeneity is present. This could allow future analysts to take test-driven stratification decisions into account when estimating variance. This approach could apply to issues with inference after model selection, or more generally, questions about inference after multiple comparisons (cf. Lee et al. 2016).

A more general issue associated with MSE is the assumption that all the elements of the population of interest have a probability greater than zero of being observed. Particularly in a wartime context, some members of the population may have probabilities of observation so small that, in practice, they are very unlikely to ever be observed. Thus MSE estimates represent only the fraction of the population with a probability of observation above some minimum level, i.e., MSE estimates are likely to be smaller than the true population size. Johndrow, Lum, and Manrique-Vallier (2019) call the minimum probability of observation 'alpha observability;' they have shown that by making explicit the level of alpha observability, the variance of the estimate can be greatly reduced. This is a classic example of balancing variance and bias, and an approach that holds great promise.

\section{Conclusions}

For social scientists seeking to understand how, why, and under what circumstances civilians are murdered during armed conflict, these results should serve as a reminder of the implausible assumptions required when raw data from casualty lists are counted, categorized, and used as the basis for quantitative analysis. By considering only the data that can be observed, analysts risk mistaking patterns in the social process of documentation with the patterns of violence being documented. The documentation dynamics may be quite different from the conflict dynamics (cf. Price, Gohdes, and Ball 2015).

In this example, note how differently the story of the conflict is told by the four raw datasets relative to the story in the dataset composed by integrating the four sources, and then different again in the multiple systems estimates. While the numerically largest dataset of lethal violence correlates well with MSE estimates over space, the same is not true over time. There is no way, a priori, to show that more data will necessarily provide a more accurate view of violence.

Finally, some substantive implications of our work are clear: The burden of vio- 
lent civilian death during the Salvadoran civil war was higher than has previously been documented, but similar to expert guesses and prior estimates. This evidence should be read as an overdue rebuke to regime apologists (e.g., Irvine and Goulden 1993; and see quotes in Gugliotti and Farah 1993), and should provide further impetus to those seeking accountability and redress for crimes committed during the war. 


\section{References}

Bacevich, A., Hallums, J., White, R., and Young, T. (1988). American military policy in small wars: The case of El Salvador. Oxford: Pergamon Press.

Bakiner, O. (2013). Truth commission impact: An assessment of how commissions influence politics and society. International Journal of Transitional Justice 8(1): 6-30. doi:10.1093/ijtj/ijt025.

Bales, K., Hesketh, O., and Silverman, B. (2015). Modern slavery in the UK: How many victims? Significance 12(3): 16-21. doi:10.1111/j.1740-9713.2015.00824.x.

Ball, P. (1996). Who did what to whom: Planning and implementing a large scale human rights data project. Washington, D.C.: American Association for the Advancement of Science.

Ball, P. (2000). Making the case: Investigating large scale human rights violations using information systems and data analysis. Washington, D.C.: American Association for the Advancement of Science.

Ball, P., Asher, J., Sulmont, D., and Manrique, D. (2003). How many Peruvians have died? An estimate of the total number of victims killed or disappeared in the armed internal conflict between 1980 and 2000. Washington, D.C.: American Association for the Advancement of Science. http://shr.aaas.org/peru/aaas_peru_5.pdf.

Ball, P., Betts, W., Scheuren, F., Dudukovich, J., and Asher, J. (2002). Killings and refugee flow in Kosovo March-June 1999: A report to the international tribunal for the former Yugoslavia. Washington, D.C.: American Association for the Advancement of Science, American Bar Association Central, and East European Law Initiative.

Ball, P. and Price, M. (2019). Using statistics to assess lethal violence in civil and inter-state war. Annual Review of Statistics and its Application 6: 63-84. doi:10.1146/annurev-statistics-030718-105222.

Berry, B. (2007). A repeated observation approach for estimating the street homeless population. Evaluation Review 31(2): 166-199. doi:10.1177/0193841X06296947.

Betancur, B., Figueredo Planchart, R., and Buergenthal, T. (1993). From madness to hope: The twelve-year war in El Salvador: Report of the United Nations Truth Commission for El Salvador. New York: United Nations. https://www.usip.org/sites/default/files/file/ElSalvador-Report.pdf.

Binford, L. (2016). The El Mozote massacre: Human rights and global implications. Revised and expanded edition. Tucson: University of Arizona Press.

Bird, S. and King, R. (2017). Multiple systems estimation (or capture-recapture esti- 
mation) to inform public policy. Annual Review of Statistics and Its Application 5(1): 95-118. doi:10.1146/annurev-statistics-031017-100641.

Bishop, Y., Fienberg, S., and Holland, P. (1975). Discrete multivariate analysis: Theory and practice. Cambridge: MIT Press.

Brunborg, H., E., T., and Urdal, H. (2006). The demography of armed conflict. International Studies in Population 33. Dordrecht: Springer.

Byrne, H. (1996). El Salvador's civil war: A study of revolution. Boulder: Lynne Rienner.

Cabarrús, C.R. (1983). Génesis de una revolución: Análisis del surgimiento y desarrollo de la Organización Campesina en El Salvador. Mexico City: Ediciones de la Casa Chata.

Danner, M. (1994). The massacre at El Mozote: A parable of the Cold War. New York: Vintage Books.

Darroch, J., Lauritzen, S., and Speed, T. (1980). Markov fields and log-linear interaction models for contingency tables. The Annals of Statistics 8(3): 522-539.

Davenport, C. and Ball, P. (2002). Views to a kill: Exploring the implications of source selection in the case of Guatemalan state terror, 1977-1995. Journal of Conflict Resolution 46(3): 427-450. doi:10.1177/0022002702046003005.

Davis, S., Strebel, P., Atkinson, W., Markowitz, L., Sutter, R., Scanlon, K., Friedman, S., and Hadler, S. (1993). Reporting efficiency during a measles outbreak in New York City, 1991. American Journal of Public Health 83(7): 1011-1015. doi:10.2105/AJPH.83.7.1011.

Galeas, G. and Ayala, E. (2008). Grandesa y miseria en una guerilla. San Salvador: Centroamérica 21.

Geibel, S., van der Elst, E., King'ola, N., Luchters, S., Davies, A., Getambu, E., Pushu, N., Graham, S., McClelland, R., and Sanders, E. (2007). 'Are you on the market?': A capture-recapture enumeration of men who sell sex to men in and around Mombasa, Kenya. AIDS 21(10): 1349-1354. doi:10.1097/QAD.0b013e328017f843.

Gelman, A. and Loken, E. (2013). The garden of forking paths: Why multiple comparisons can be a problem, even when there is no 'fishing expedition' or 'p-hacking' and the research hypothesis was posited ahead of time [unpublished manuscript]. New York: Columbia University. http://www.stat.columbia.edu/g̃elman/research/unpublished/p_hacking.pdf.

Gignoux, E., Idowu, R., Bawo, L., Hurum, L., Sprecher, A., Bastard, M., and Porten, K. (2015). Use of capture-recapture to estimate underreporting of Ebola Virus Disease, Montserrado County, Liberia. Emerging Infectious Diseases 21(12): 2265-2267. 
doi:10.3201/eid2112.150756.

Gould, J. and Lauria-Santiago, A. (2009). To rise in darkness: Revolution, repression, and memory in El Salvador, 1920-1932. Durham: Duke University Press.

Gugliotti, G. and Farah, D. (1993, March 21). 12 years of tortured truth on El Salvador. Washington Post. https://www.washingtonpost.com/archive/politics/1993/03/21/12years-of-tortured-truth-on-el-salvador/9432bb6f-fbd0-4b18-b254-29caa919dc98/.

Hartigan, J. and Hartigan, P. (1985). The dip test of unimodality. The Annals of Statistics 13(1): 70-84.

Hoover Green, A. (2011). Repertoires of violence against noncombatants: The role of armed group institutions and ideology [PhD Thesis]. New Haven: Yale University, Department of Political Science.

Howland, T. (2008). How El Rescate, a small nongovernmental organization, contributed to the transformation of the human rights situation in El Salvador. Human Rights Quarterly 30(1): 703-757.

Irvine, R. and Goulden, J. (1990). US Left's ‘big lie' about El Salvador deaths. Human Events 15 September, 1990: 787.

Jansson, A., Arneborn, M., and Ekdahl, K. (2005). Sensitivity of the Swedish statutory surveillance system for communicable diseases 1998-2002, assessed by the capture-recapture method. Epidemiology and Infection 133(3): 401-407. doi: $10.1017 / \mathrm{S} 0950268804003632$.

Johndrow, J., Lum, K., and Ball, P. (2015). dga: Capture-recapture estimation using Bayesian model averaging [electronic resource]. Vienna: R Foundation for Statistical Computing. https://cran.r-project.org/web/packages/dga/index.html.

Johndrow, J., Lum, K., and Manrique-Vallier, D. (2019). Low-risk population size estimates in the presence of capture heterogeneity. Biometrika 106(1): 197-210. doi:10.1093/biomet/asy065.

Kendall, W. (1999). Robustness of closed capture-recapture methods to violations of the closure assumption. Ecology 80(8): 2517-2525. doi:10.2307/177237.

Krüger, J. and Ball, P. (2014). Evaluation of the database of the Kosovo Memory Book [electronic resource]. San Francisco: Human Rights Data Analysis Group. https://hrdag.org/wp-content/uploads/2015/04/Evaluation_of_the_Database_KMB2014.pdf.

Lee, J., Sun, D., Sun, Y., and Taylor, J. (2016). Exact post-selection inference, with application to the lasso. Annals of Statistics 44(3): 907-927. doi:10.1214/15-AOS1371. 
Lewden, C., Jougla, E., Alioum, A., Pavillon, G., Lièvre, L., Morlat, P., Salmon, D., May, T., and Chêne, G. (2006). Number of deaths among HIV-infected adults in France in 2000, three-source capture-recapture estimation. Epidemiology and Infection 134(6): 1345-1352. doi:10.1017/S095026880600639X.

Lum, K., Price, M., and Banks, D. (2013). Applications of multiple systems estimation in human rights research. The American Statistician 67(4): 191-200. doi:10.1080/00031305.2013.821093.

Lum, K., Price, M., Guberek, T., and Ball, P. (2010). Measuring elusive populations with Bayesian model averaging for multiple systems estimation: A case study on lethal violations in Casanare, 1998-2007. Statistics, Politics, and Policy 1(1): n.p. doi:10.2202/2151-7509.1005.

Madigan, D. and York, J. (1997). Bayesian methods for estimation of the size of a closed population. Biometrika 84(1): 19-31. doi:10.1093/biomet/84.1.19.

Mastro, T., Kitayaporn, D., Weniger, B.G., Vanichseni, S., Laosunthorn, V., Uneklabh, T., Uneklabh, C., Choopanya, K., and Limpakarnjanarat, K. (1994). Estimating the number of HIV-infected injection drug users in Bangkok: A capture-recapture method. American Journal of Public Health 84(7): 1094-1099. doi:10.2105/ajph.84.7.1094.

Montgomery, T. (2018). Revolution in El Salvador: From civil strife to civil peace. London: Routledge.

Popkin, M. and Roht-Arriaza, N. (1995). Truth as justice: Investigatory commissions in Latin America. Law and Social Inquiry 20(1): 79-116. doi:10.1111/j.17474469.1995.tb00683.x.

Price, M., Gohdes, A., and Ball, P. (2015). Documents of war: Understanding the Syrian conflict. Significance 12: 14-19. doi:10.1111/j.1740-9713.2015.00811.x.

Schwarz, B. (1991). American counterinsurgency doctrine and El Salvador: The frustrations of reform and the illusions of nation building. Santa Monica: RAND Corporation.

Sekar, C. and Deming, W. (1949). On a method of estimating birth and death rates and the extent of registration. Journal of the American Statistical Association 44(245): 101-115. doi:10.1080/01621459.1949.10483294.

Seligson, M. and McElhinny, V. (1996). Low-intensity warfare, high-intensity death: The demographic impact of the wars in El Salvador and Nicaragua. Canadian Journal of Latin American and Caribbean Studies 21(42): 211-241. doi:10.1080/08263663.1996.10816742.

Spiegel, P. and Salama, P. (2000). War and mortality in Kosovo, 1998-1999: An epidemiological testimony. Lancet 355(9222): 2204-2209. doi:10.1016/S0140- 
6736(00)02404-1.

Stanley, W. (1996). The protection racket state: Elite politics, military extortion, and civil war in El Salvador. Philadelphia: Temple University Press.

Tabeau, D. (2009). Conflict in numbers: Casualties of the 1990s wars in the former Yugoslavia (1991-1999). Testemonies 33. Belgrade: Helsinki Committee for Human Rights.

United Nations (2017). World population prospects: The 2017 revision [electronic resource]. New York: United Nations, Department of Economic and Social Affairs, Population Division. https://www.un.org/development/desa/publications/worldpopulation-prospects-the-2017-revision.html.

Van Hest, N., Story, A., Grant, A., Antoine, D., Crofts, J., and Watson, J. (2008). Recordlinkage and capture-recapture analysis to estimate the incidence and completeness of reporting of tuberculosis in England 1999-2002. Epidemiology and Infection 136(12): 1606-1616. doi:10.1017/S0950268808000496.

Viterna, J. (2013). Women in war: The micro-processes of mobilization in El Salvador. New York: Oxford University Press.

Wood, E. (2003). Insurgent collective action and civil war in El Salvador. New York: Cambridge University Press. 